\title{
Assessment of Soil Chemical Properties and Coffee Leaf Analysis in Goma Woreda of Oromia Region
}

\author{
Mohammed Kedir*, Taye Kufa, Bayu Dume \\ Jimma Agricultural Research Center, Jimma, Ethiopia \\ Email address: \\ muhech2006@gmail.com (M. Kedir) \\ ${ }^{*}$ Corresponding author

\section{To cite this article:} \\ Mohammed Kedir, Taye Kufa, Bayu Dume. Assessment of Soil Chemical Properties and Coffee Leaf Analysis in Goma Woreda of Oromia \\ Region. Agriculture, Forestry and Fisheries. Vol. 10, No. 3, 2021, pp. 93-101. doi: 10.11648/j.aff.20211003.11
}

Received: March 20, 2021; Accepted: May 21, 2021; Published: May 27, 2021

\begin{abstract}
Information on soil test and plant analysis is essential for sustainable soil fertility management and crop production. Conversely, this is lacking for smallholder coffee farms in Gomma district, Southwestern Ethiopia. Thus, the objectives of this study were to assess and determine the nutritional status of the soil-plant relation from coffee growing farms in Gomma district. Accordingly, soil samples, coffee leaves and field history were collected from 10 coffee farms during pinhead phase. Soil samples collected from 0-30 cm depth were prepared and analyzed in the laboratory following standard procedures. For data analysis, descriptive statistics was used. Results showed that the soil $\mathrm{pH}$ ranged from strongly to moderately acidic $(\mathrm{pH} 4.72-5.75)$ and low to medium in their organic matter $(2.68-4.72 \%)$ content. Total $\mathrm{N}$ content was low in $20 \%$ of the samples, while $100 \%$ of the soil samples found to be deficient in P content. Exchangeable Ca ranged from low to high, exchangeable $\mathrm{Mg}$ in all soil samples was medium, while exchangeable $\mathrm{K}$ ranged medium to very high. Nevertheless, $\mathrm{K}$ to $\mathrm{Mg}$ ratio varied from $0.64: 1$ to $2.62: 1$, indicating $\mathrm{Mg}$ induced $\mathrm{K}$ deficiency in $10 \%$. The plant tissue analysis depicted that 50 , 60 and 50\% low in N, P and K, respectively, while high in Ca and Mg concentrations. Significant and positive correlations of soil phosphorus, potassium, calcium and magnesium with tissue concentration were existed. For sound conclusion, soil test and crop response calibration, appropriate soil, N, P, K, organic fertilizers and lime are recommended for future work.
\end{abstract}

Keywords: Correlation, Plant Analysis, Soil Properties, Soil Test, Yield

\section{Introduction}

Coffee is most important and backbone of Ethiopian economy, which accounts for an average $5 \%$ of GDP, $10 \%$ of the total agriculture production and $60 \%$ of export earnings [23]. Despite its importance, the national average yield of coffee is about $0.67 \mathrm{t} \mathrm{ha}^{-1}$ [11]. This is by far below the Brazil's average yield, which is about $1.5 \mathrm{t} \mathrm{ha}^{-1}$ [3]. This yield gap of coffee is attributed to a number of factors like, declining of soil fertility, poor agronomic practice, limited use of input, insufficient technology generation, lack of credit facilities, poor seed quality, which in turn critically hinders the productivity of the smallholder coffee farmer in the country [41].

Land degradation and soil nutrient depletion have become serious threats to agricultural productivity in Sub-Saharan Africa. Ethiopia is one of countries Sub-Saharan Africa that, a declining in soil fertility is the major challenge to increase crop production [4]. Accordingly, the depletion rate of macronutrients $\mathrm{N}, \mathrm{P}$ and $\mathrm{K}$ were 122,13 and $82 \mathrm{~kg} \mathrm{ha}^{-1}$ year $^{-1}$ in Ethiopia, respectively [5]. This might be associated to the loss of organic matter, biomass and animal manure removal from farm plots and limited application of mineral and organic fertilizers, macro and micronutrient depletion, soil acidity and topsoil erosion [27, 29]. Therefore, decline in soil fertility resulted in low yield [18] which is a serious threat to Ethiopian country.

Site specific and balanced fertilizer recommendations are used for not only sustainable soil fertility management and crop production, but used also as reduced environmental impacts and minimized farmers from unnecessary costs. For instance, from 30 to $55 \%$ of an application of $250 \mathrm{~kg} \cdot \mathrm{ha}^{-1}$ of urea-N was leached as $\mathrm{NO}^{-3}$ [9]. Such significant net loss of $\mathrm{N}$ causes important environmental concerns such as water contamination, soil acidification, greenhouse gas emissions or $\mathrm{N}$ volatilization, as well as economic impacts that threaten 
sustainability and the coffee farmer's livelihood. Therefore, irrespective of knowing status of soil nutrients, applications of fertilizers to crops are not significant changes.

Currently, various researches conducted on soil fertility status in different agro-ecologies of Ethiopia. For instance, as reported by [2, 47, 42], the deficiency of $\mathrm{K}$ in some Ethiopian soils. Many soils in Ethiopia are poor in available plant nutrients and organic matter content [1, 4]. Recently, the results of national soil fertility mapping initiative has also indicated that other nutrients including $\mathrm{K}, \mathrm{S}, \mathrm{Fe}, \mathrm{Zn}$ and $\mathrm{B}$ are also found to be deficient in Ethiopian soils [17]. The soil nutrient status of cassava farms was conducted by Fanuel et al. [19] in Southern part of Ethiopia, who found that S, exchangeable $\mathrm{Ca}$ and $\mathrm{Mg}$ induced $\mathrm{K}$ deficiency were observed to be deficient on cassava farms. However, still data on soil nutrient status under coffee soils is limited to Gomma district. Similarly, fertilizer application is depended on blanket recommendation because there is no fertilizer recommendation guideline based on soil test and plant tissue analysis of soils the study area. Hence, to tackle these serious issues, call for site specific and balanced for sustainable soil nutrient management, coffee production and food security in study area.

In the same way, soil tests commonly used to assess the sufficiency or deficiency of essential plant nutrients. Nevertheless, soil tests provide information about a soil capacity to supply plant available nutrients it is an indirect measurement. In addition, the findings of the soil diagnosis and leaf diagnosis were not entirely consistent [25, 18, 38]. Following this, Sousa et al. [40] reported that analysis of plant-soil nutrient relationship could use as a guideline to determine the fertilizer recommendation. As a result, it is advantageous to combine these two methods accurately identify the status and presence of nutrients. Therefore, the objectives of this study were to assess and determine the nutritional status of the soil-plant relation from coffee growing farms in Gomma district.

\section{Materials and Methods}

\subsection{Description of the Study Area}

The study was conducted in Gomma district, Jimma zone of the Oromia national state, located in mid altitude subhumid zone of the Southwestern Ethiopia. Gomma district is located $397 \mathrm{~km}$ to southwest of capital Addis Ababa and 50 $\mathrm{km}$ away from Jimma town. The topography of the study area ranges from gently sloping to hilly lands with ridges and valleys in between. Altitudinal range of the district is between 1387 to 2870 m.a.s.l [28].

The Gomma district is characterized by bi-modal rainfall distribution with an average annual rainfall of $1534 \mathrm{~mm}$. The mean maximum and minimum air temperature is $28.7^{\circ} \mathbf{C}$ and $11.9{ }^{\circ} \mathbf{C}$, respectively. The small rains are from March to April and the main rainy season extends from June to October. There are about seven rainfall months. Agroecologically, the district is divided into $8 \%$ high land (Dega), $88 \%$, intermediate high land (Weyina Dega) and 4\% low land
(Kolla) [28].

Soils: The Eutric Vertisols, Humic Alfisols and Humic Nitisols are the three dominant soil types in Gomma district with Nitisols being the most abundant soil type (about 90\%) of the district. These soils are generally acidic soils with $\mathrm{pH}$ values ranging between 4.5 and 5.5 [28].

Coffee/livestock farming system: Thirty-two kebeles with more than $92 \%$ of the people in Gomma are categorized under this smallholder coffee farming system. The major cash crop commodities in this farming system include; coffee, khat (Catha edulis), tropical and sub-tropical fruits (mango, avocado, papaya, banana, orange, pineapple) and spices (mainly ginger and Ethiopian cardamom). Among cereals, maize, teff, barely are grown in the area; amongst of which, maize is the dominant cereal crop in the farming system. Livestock commodities include; cattle, small ruminants (sheep and goat) apiculture, poultry and equines. Sheep are larger in number than goats in this farming systems [28].

\subsection{Field Survey, Site Selection, Soil Sampling and Sampling Techniques}

\section{Soil Sampling}

Soil samples were taken from locations having similar, topography and similar land use history. Accordingly, a total ten (10) composited soil samples were collected randomly from coffee growing farms of selected coffee farms. The soil samples were collected $0-30 \mathrm{~cm}$ depth by using auger. Twelve (12) sub-samples were collected in a zigzag method and finally composited. For each main sampling point, after removing unnecessary material such as roots, clods and stones and thoroughly mixed together in the clean bucket, about $1 \mathrm{~kg}$ of representative composite soil sample collected and logged into properly labeled sample bag.

Soil samples were not taken from unusual areas like animal dung accumulation places, poorly drained and any other places that cannot give representative soil samples. During soil sampling, the following variables were collected: latitude, longitude and altitude were measured by using GPS, slope was measured by using clinometers, topography, types and rates of fertilizer applied, lime applied were recorded, and finally were brought to Soil Laboratory of Jimma Agricultural Research Center.

\subsection{Soil Sample Preparation and Soil Laboratory Analysis}

The soil samples were collected from the study area air dried, crushed and passed through a $2 \mathrm{~mm}$ diameter sieve for all parameters except total $\mathrm{N}$ and $\mathrm{OC}$ that passed through a $0.5 \mathrm{~mm}$ diameter selected soil physical and chemical properties were analyzed at soil laboratory of Jimma agricultural research center. Soil $\mathrm{pH}$ was determined in a 1:2.5 soil to water ratio using a digital $\mathrm{pH}$-meter [44]. Organic carbon was determined following the wet digestion method as described by [46] while percentage organic matters of the soils were determined by multiplying the percent organic carbon value by 1.724 . Total $\mathrm{N}$ of the soil was determined by the Micro-Kjeldahl digestion, distillation 
and titration method [8]. Available P was determined using the Bray II method by shaking the soil samples with an extracting solution of $0.03 \mathrm{M}$ ammonium fluoride in $0.01 \mathrm{M}$ hydrochloric acid as described by [7].

Exchangeable bases were extracted with $1 \mathrm{~N}$ ammonium acetate at $\mathrm{pH}$ 7. Exchangeable $\mathrm{Ca}$ and $\mathrm{Mg}$ were measured by atomic absorption spectrophotometer (AAS), while exchangeable $\mathrm{Na}$ and $\mathrm{K}$ were measured by flame photometer [37]. For the determination of CEC, the soil samples leached with $1 \mathrm{~N}$ ammonium acetate solution and washed with ethanol (97\%) to remove excess salt followed by leaching with sodium chloride to displace the adsorbed $\left(\mathrm{NH}_{4}^{+}\right)$. The quantity of ammonia then was measured by distillation and taken as CEC of the soil [10]. The percent base saturation of the soils was calculated as the percentage of the sum of the basic exchangeable cations $(\mathrm{Ca}, \mathrm{Mg}, \mathrm{K}$ and $\mathrm{Na}$ ) to the $\mathrm{CEC}[6]$.

\subsection{Plant Tissue Sampling}

Coffee leaf samples were collected with clean hands before taking soil samples in order to avoid contamination. Following guideline of [13], leaf samples were collected when the fruit was in the pinhead stage, between the flowering phase and the first phase of rapid fruit expansion, by removing newly mature leaves with petioles from the $3 \mathrm{rd}$ or 4th pairs of leaves from the apex of the branch, in the middle part of the plants, from all cardinal directions. In each farm, 20 plants were chosen at random, and two pairs of leaves were removed from each plant, for a total of 80 leaves per uniform plot. Accordingly, soil and coffee leaf samplings were carried out on the same day, and from the same farms.

Care was taken to take plant samples that are free of disease and was collected using clean scissors. The samples were washed with distilled water to avoid any contamination by dust from the soil or other sources. The collected plant samples were put in paper bags, air-dried in a dust free room, transferred into plastic bags, and tagged.

Plant Leaf Preparation and Laboratory Analysis

Coffee leaf samples were firstly washed with distilled water, oven dried at $60-70{ }^{\circ} \mathrm{C}$ to a constant weight, ground, passed through 2-mm sieve and placed in paper bags. Total nitrogen in plants was determined using Kjeldahl digestion procedure as described by [8]. Plant digests (using concentrated $\mathrm{HNO}_{3}$ and $30 \% \quad \mathrm{H}_{2} \mathrm{O}_{2}$ ) was prepared and analyzed for $\mathrm{Ca}$ and $\mathrm{Mg}$ using Atomic Absorption Spectrophotometer while $\mathrm{P}$ concentration of the digests were measured with a spectrophotometer and the $\mathrm{K}$ concentration with a flame photometer.

\subsection{Statistical Data Analysis}

Descriptive statistics such as mean, minimum and maximum were employed for the study. Correlation analysis was employed to assess the association between soil variables and coffee leaves. For data analysis, Statistical Package for Social Science version 16 (SPSS) was used.

\section{Results and Discussion}

\subsection{Soil Chemical Properties}

\subsubsection{Soil pH}

The soil $\mathrm{pH}$ of coffee farms varied from 4.72 to 5.75 with a mean value of 5.33 (Table 1). Based on rating of [16], about 70 and $30 \%$ of the samples in the study area were found to be strongly acidic $(\mathrm{pH}<5.5)$ and moderately acidic (5.6-6.5), respectively. The result was in agreement with [1] found that soils were acidic in the southwestern Ethiopia. Higher soil acidity in coffee farms could be attributed to the loss of basic cations through runoff and erosion, warm temperature, high rainfall and intensive cultivation in the study area. This in turn increases the activity of $\mathrm{H}^{+}$ion in the soil solution and reduces soil $\mathrm{pH}$. This is agreement with the findings of [1] who reported that loss of base forming cations through leaching and runoff generated from accelerated erosion reduces soil $\mathrm{pH}$ and thereby increases soil acidity. Thus, about $70 \%$ of the sampled fields found to be not favorable in terms of $\mathrm{pH}$ for sustainable coffee production, which requires liming and/or organic material application.

Table 1. Soil fertility parameters of coffee growing farms.

\begin{tabular}{lllllll}
\hline \multirow{2}{*}{ Descriptive Statistics } & \multicolumn{2}{l}{ Soil Fertility Parameters } & & & \\
\cline { 2 - 7 } & $\mathbf{p H}$ & OC (\%) & OM (\%) & C/N & TN (\%) & AvP (ppm) \\
\hline Mean & 5.33 & 2.11 & 3.64 & 10.89 & 0.207 & 2.05 \\
Minimum & 4.72 & 1.55 & 2.68 & 6.55 & 0.10 & 0.64 \\
Maximum & 5.75 & 2.74 & 4.72 & 16.25 & 0.276 & 4.13 \\
\hline
\end{tabular}

$\mathrm{AvP}=$ available phosphorus

\subsubsection{Organic Matter and Carbon to Nitrogen Ratio}

Organic matter amounts of soil samples ranged from 2.68 to $4.72 \%$ with a mean value of $3.64 \%$ (Table 1 ). Accordingly, the soil OM is categorized under low (2-3\%) to optimum (3$7 \%$ ) range based on the critical level suggested by [16]. However, the majority (90\%) of coffee growing fields were found to be optimum in soil organic matter. The high level of soil organic matter in the study area could be attributed to the addition of coffee leaves, shade tree leaves and weed residues into the soils. This current study agreed with that of [35] who reported that the high soil organic matter could be because of ample litter cover, organic inputs, root growth and decay, and abundant burrowing fauna. On the other hand, it is not expected for the organic matter to supply sufficient nutrients (especially $\mathrm{N}$ ) to sustain high yields, due to the lack of synchronization in $\mathrm{N}$ mineralization and plant uptake, and the large amounts of $\mathrm{N}$ that are needed by coffee to sustain high yields [33]. Deficient in organic matter could be 
characterized by the complete removal of biomass from the field, lower application rate of fertilizers and continuous cultivation that exacerbates rapid rate of mineralization [25].

The Carbon to nitrogen ratio of soil-sampled soils ranged from 6.55 to $16.25 \%$ with a mean of $10.89 \%$ (Table 1 ). The carbon to nitrogen ratio; however, about $60 \%$ of sampled soils were below the critical level $(<10)$ and the remained soil samples were within critical level set by (Sanchez et al., 1982). The $\mathrm{C} / \mathrm{N}$ ratio also states the rate of OM decomposition. As the $\mathrm{C} / \mathrm{N}$ ratios in the examined coffee farms were much lower than this level, the immobilization of inorganic $\mathrm{N}$ may not be of a major concern in study sites. In this study, $\mathrm{C} / \mathrm{N}$ ratios are close to levels considered ideal for optimum $\mathrm{N}$ mineralization from $\mathrm{OM}$.

\subsubsection{Total Nitrogen}

Data on total nitrogen of the soil samples are presented in Table 1. Total nitrogen content also varied between 0.1 to $0.276 \%$; in which about $20 \%$ of sampled soils were rated as low $(<0.15 \%)$ and $80 \%$ optimum $(0.15-0.3 \%)$ [16] for coffee production. In terms of $\mathrm{TN}$, coffee farms of study area were adequate for coffee in $\mathrm{TN}(80 \%)$. A possible reason for the high $\mathrm{TN}$ is that leguminous shade trees, residues of weed remained in farms; litter of coffee leaves could be decomposed and transformed into soils. Total nitrogen content also followed the distribution patterns of soil organic matter. As a result, significant and positive correlation $(\mathrm{r}=$ 0.69) was observed between TN and soil OM. This present study is agreement with findings of [4] who revealed that TN was determined by soil organic matter.

Conversely, total $\mathrm{N}$ is not a reliable indicator of $\mathrm{N}$ availability but it includes all forms of inorganic and organic soil N. Thus, $\mathrm{N}$ management practices should be dependable on expected yields and site-specific empirical assessments between fertilizer $\mathrm{N}$ application and economic crop response.

Lower content of TN could be due to leaching of $\mathrm{N}$ because of high rainfall, soil erosion due to steep slopes, no external input ( $\mathrm{N}$ containing fertilizer and organic fertilizers) and nutrient removed by harvested products without nutrient replenishment in the study area. This finding is supported by the results of those $[1,18,4]$ showed the loss in nitrogen was due to complete removal of biomass from the field, lower application rate of fertilizers and continuous cultivation that aggravates rapid rate of mineralization. Thus, absence in nitrogen content can be characterized by reduction in macronutrients content in the aerial part, roots and nutrients absorption [22].

\subsubsection{Available Phosphorus}

The descriptive statistics of available phosphorus is shown in Table 1. The available phosphorus content varied from 0.64 to $4.13 \mathrm{ppm}$ with a mean value of $2.05 \mathrm{ppm}$. According to
EthioSIS [16], all of the soil samples (100\%) were very low (< $15 \mathrm{ppm}$ ) category in available phosphorus status in the study sites. The low content of available phosphorus is because of low $\mathrm{pH}$, nutrient mining, continuous crop uptake, losses due to erosion and fixation by acidic soils and no external input like $\mathrm{P}$ fertilizer and organic fertilizer in coffee growing fields of study area. This study is in line with the findings of [4, 18 29] who reported that most of Ethiopian soils are deficient in available phosphorus concentration due to low $\mathrm{pH}$ (acidic), the intensive cropping system, imbalanced use of fertilizer and nutrient mining. Similarly, numerous studies also have proved that low available $\mathrm{P}$ content in cultivated fields as compared to other land use types $[45,34]$.

The second reason is that, absence of lime application is a major influence on available P contents. Similarly, 35.63 ppm available $\mathrm{P}$ was recorded under treatment received lime, whereas $2.1 \mathrm{ppm}$ available $\mathrm{P}$ was observed under control treatment [12] which is very far variation. Research clearly indicated that lime was not the only available P constraining factor but also treatment-applied lime increased coffee cherry yield by $60.5 \%$ than control treatment [12]. Thus, to increase soil $\mathrm{pH}$ and decrease aluminum saturation, and by enhancing nutrient availability lime is required to the study area.

\subsubsection{Exchangeable Bases, Cation Exchange Capacity and Percentage of Base Saturation}

\section{(i). Exchangeable Calcium}

Data on exchangeable calcium of the soil samples are presented in Table 2. Exchangeable $\mathrm{Ca}$ ranged from 1.8 to $6.03 \mathrm{meq} / 100 \mathrm{~g}$ which is rated as low $(<3 \mathrm{meq} / 100 \mathrm{~g})$, optimum (3-5 meq/100g) and high ( $>5$ meq/100g) categories as critical level suggested by [39]. The exchangeable calcium content also followed the trend of organic matter which was $90 \%$ of soil samples were found to be sufficient for coffee production. This result agreed with findings of [4] who reported that the majority of sampled soils tended to be above critical values that could be attributed to the nature of the parent material.

Nevertheless, about $10 \%$ of soil samples were observed low in exchangeable calcium in the coffee growing farms. Low in Ca content may be as a result of low soil $\mathrm{pH}$, leaching due to high rainfall and impact of landscape positions in study sites. In southern Ethiopia, soils of maize and cassava growing farms were low in Ca content $[18,19]$. In this study, factor causes exchangeable calcium below accepted level might be attributed to un-limed coffee farms in the study sites. This is in line with Cyamweshi et al. [12] depicted that exchangeable calcium affected by lime application it increased from 3.12 (meq/100g) control treatment to 4.45 $(\mathrm{meq} / 100 \mathrm{~g})$ lime received treatment.

Table 2. Descriptive statistics of basic cations and CEC (meq/100g).

\begin{tabular}{lllllll}
\hline \multirow{2}{*}{ Descriptive Statistics } & \multicolumn{2}{l}{ Exchangeable cations (meq/100g) } & & & \\
\cline { 2 - 6 } & Ca & Mg & K & Na & K:Mg & CEC \\
\hline Mean & 4.07 & 1.39 & 2.35 & 0.19 & 1.68 & 19.85 \\
Minimum & 1.80 & 1.10 & 0.98 & 0.07 & 0.64 & 14.88 \\
Maximum & 6.03 & 1.52 & 3.85 & 0.38 & 2.62 & 25.08 \\
\hline
\end{tabular}




\section{(ii). Exchangeable Magnesium}

The descriptive statistics of exchangeable magnesium is shown in Table 2. The exchangeable magnesium content varied from 1.1 to $1.52 \mathrm{meq} / 100 \mathrm{~g}$ with a mean value of 1.39 meq/100g. The exchangeable magnesium of all soil sites falling within the medium ( 0.5 to $2.5 \mathrm{meq} / 100 \mathrm{~g})$ category as per the rating suggested by [26] which is optimum for coffee production. A possible reason for optimum $\mathrm{Mg}^{2+}$ is that, impact shade trees and high organic matter in coffee farms. However, magnesium content below critical range was observed in south part of Ethiopia [18]. Similarly, Alemu et al. [4] reported not only calcium induced $\mathrm{Mg}$ deficiency but also $\mathrm{K}$ induced $\mathrm{Mg}$ deficiency was recorded in Ethiopian soils. Therefore, it should be worked on balanced nutrient by avoiding nutrient imbalance, which does not tend farmers to additional expense and negative impacts on environments.

\section{(iii). Exchangeable Potassium and Potassium-to Mg Ratios}

The results of exchangeable potassium, as presented in Table 2, revealed that the exchangeable potassium ranged from 0.98 to $3.85 \mathrm{meq} / 100 \mathrm{~g}$ with a mean value of 2.35 meq/100g. Accordingly, as per the rating suggested by [16], about 20, 40 and $40 \%$ of sampled soils in Gomma district across coffee growing farms under optimum (0.51-1.5 meq/100g), high (1.51-2.3 meq/100g) and very high $(>2.31$ $\mathrm{meq} / 100 \mathrm{~g}$ ) categories, respectively, in exchangeable $\mathrm{K}$. This reason for high amount of potassium could be due to the presence of high organic matter and clay content in soils of the study area. Nath [32] also observed similar result. As findings indicated by [25, 4, 29], high-level potassium in soils of southwestern, central highland, southern and northeastern of Ethiopia, respectively.

However, Mg induced K deficiency was recorded by [18] Thus, it should pay attention to apply $\mathrm{K}$ fertilizer without consideration of optimum $\mathrm{K}$ level in soil because there is a competition with nutrient, which does not make $\mathrm{K}$ availability to plants.

The descriptive statistics of the Potassium-to- $\mathrm{Mg}$ ratio of the different coffee growing farms showed that the Potassium-to- $\mathrm{Mg}$ ratio ranged from 0.64 to 2.62 (Table 2). This result implies that Potassium-to-Mg ratio, about $90 \%$ of sampled soils were greater than 0.7 as critical level suggested by [31] which was sufficient for crop production. Alemu et al. [4] also reported similar result. On the other hand, among soil samples, around $10 \%$ were low in Potassium-to-Mg ratio content, which was below the recommended range $(<0.7)$ [31]. This is in agreement with the findings of $[25,18]$ who reported that $\mathrm{Mg}$ induced $\mathrm{K}$ deficiency were observed in wheat farms in Vertisols of central highland, maize and cassava farms in Nitisols of southern of Ethiopia, respectively.

The Lower values of Potassium-to-Mg ratio may be linked to $\mathrm{K}$ adsorption to cation exchange sites, $\mathrm{K}$ fixation capacity of clay mineral and continuous $\mathrm{K}$ removal without application of $\mathrm{K}$ containing fertilizers [25, 18]. Similarly, According to Fanuel et al. (2018) who concluded that soil exchangeable K values alone may not adequately indicate $\mathrm{K}$ availability. Therefore, soils of the study area could do with soil fertility improvement with addition of $\mathrm{K}$ fertilizer and organic fertilizer to soil in order to make better and sustain crop coffee production for study area.

\section{(iv). Exchangeable Sodium}

Sodium $(\mathrm{Na})$, though is not an essential element for plant growth, but is important for diagnosing problem soils that may contain high amounts of sodium. High levels of exchangeable sodium affect soil structure, soil permeability and may be toxic to sensitive plants [26]. Data on exchangeable sodium of the soil samples are presented in Table 2. Exchangeable sodium $\left(\mathrm{Na}^{+}\right)$ varied from 0.07 to $0.38 \mathrm{meq} / 100 \mathrm{~g}$ in Gomma district, indicating wide variability among sampled soils across coffee growing farms. Accordingly, sampled soils in Gomma district through coffee growing farms fall in under optimum $(<1.0$ meq/100 g category, based on the critical level suggested by [39].

\section{(v). Cation Exchangeable Capacity}

The CEC ranged from 14.88 to $25.08 \mathrm{meq} / 100 \mathrm{~g}$ with a mean value of $19.85 \mathrm{meq} / 100 \mathrm{~g}$ in the coffee growing farms. Following this, according to [30], all of sampled soils were fallen in high $(>12 \mathrm{meq} / 100 \mathrm{~g})$ category in CEC. High in CEC contents might be explained the presence of high clay content, the predominance of 2:1 clay minerals, high organic matter and parent material from which soil was formed. Hillette et al. [25] observed similar findings. Despite of high CEC, soil and water conservation efforts are necessitated to improve soil fertility by reducing nutrients loss due to the soil runoff in coffee farms of study area.

\section{(vi). Percentage of Base Saturation}

The result revealed percentage of base saturation (PBS) content of the soils of the study area as shown in Table 2. The percentage of base saturation (PBS) varied from 24.92 to $51.12 \%$ in the coffee growing farms. Based on abovementioned, about 40 and $60 \%$ of the soil samples were found to be low (20-40\%) and medium (40-60\%) critical level suggested by [48], respectively in PBS. The factors that cause low in PBS could probably be because of low $\mathrm{pH}$, removal of basic cation from top soil, landscape positions and accumulation of sand particles in the sites.

\subsection{Coffee Leaf Nutrient Status}

\subsubsection{Leaf Nitrogen Content}

The tissue $\mathrm{N}$ content varied from 1.64 to $4.07 \%$ with a mean of $2.66 \%$ (Table 3 ). Correspondingly, about 50, 20 and $30 \%$ of the study sites were found to be low $(<2.5 \%)$, medium $(2.5$ $3 \%$ ) and ( $>3 \%$ ) high category as critical level suggested by [36], respectively in leaf $\mathrm{N}$ concentration. The current study suggests that there was insufficient $\mathrm{N}$ content in the coffee leaves in $50 \%$. On comparative basis, the deficient in leaf $\mathrm{N}$ concentration was reflected more than the total nitrogen status in the soil test. There was in-significantly and weakly correlated $\mathrm{N}$ tissue with total $\mathrm{N}$ (Table 4). This current result implies total nitrogen values were inconsistent with plant 
tissue analysis thus without consideration of plant tissue analysis it is not applicable for fertilizer recommendation.

Table 3. Descriptive statistics of coffee leaf concentrations.

\begin{tabular}{llllll}
\hline Descriptive & \multicolumn{2}{l}{ Nutrient } & & \\
\cline { 2 - 6 } Statistics & N (\%) & P (\%) & K (\%) & Ca (\%) & Mg (\%) \\
\hline Mean & 2.66 & 0.14 & 1.85 & 1.02 & 0.31 \\
Minimum & 1.64 & 0.11 & 1.31 & 0.75 & 0.25 \\
Maximum & 4.07 & 0.17 & 2.59 & 1.50 & 0.39 \\
\hline
\end{tabular}

The deficiency of coffee leaf $\mathrm{N}$ content might be associated with coffee age, no application of mineral and organic fertilization in the study area. Similarly, treatment with the full nutrient solution reflected $3.73 \%$ of $\mathrm{N}$ content, whereas absence of $\mathrm{N}$ reduced aerial part content to $1.84 \%$ [22] which was below the critical value. Moreover, low in leaf $\mathrm{N}$ concentration reflected harvest of coffee berries without soil nutrient replenishment resulted in nutrient extraction, continued coffee production without application of fertilizers, which resulted in depletion of nutrients and loss of $\mathrm{N}$ due to leaching. Apart from those, Coffee leaf $\mathrm{N}$ contents are not only affected by fertilization but also significantly influenced by the sampling time of plant tissue [15].

\subsubsection{Leaf Phosphorus Content}

Phosphorus concentration in coffee leaves ranged from 0.11 to $0.17 \%$ with a mean of $0.14 \%$ in Table 3 . According to Reuter and Robinson [36] ratings showed that about $60 \%$ of the sampled coffee leaves were found to be deficient $(<$ $0.15 \%$ ) in available $\mathrm{P}$ concentration. Available $\mathrm{P}$ was deficient in samples from all sites, whereas about $40 \%$ of tissue $\mathrm{P}$ contents were recorded within sufficient range, which was not reflected in the soil test.

Deficiency in tissue $\mathrm{P}$ content could be attributed to low available $\mathrm{P}$ in soils, no application of chemical fertilizer and organic fertilizer, and low soil $\mathrm{pH}$. $\mathrm{P}$ tissue concentration was significant and positive association $(\mathrm{r}=0.87)$ with soil $\mathrm{P}$ content (Table 4). Flores et al. [22] who observed that the treatment with $\mathrm{P}$ absence reduced tissue $\mathrm{P}$ contents in the aerial part by $25 \%$ comparable with fully received phosphorus fertilization supported this result. Similarly, plant tissue deficiency was recorded on wheat and maize leaves in Ethiopia were reported by [25, 18]. The second reason for inadequate leaf $\mathrm{P}$ content could be due to coffee age. This result was corroborated with [24] who reported that the older coffee age was lower than younger coffee in leaf $\mathrm{P}$ concentration. Therefore, phosphorus deficiency led to the reduction in the number of leaves, relative chlorophyll index, in $\mathrm{CO}_{2}$ concentration and a lower dry matter production in the roots, compared to treatments with the full nutrient solution [22].

\subsubsection{Leaf Potassium Content}

Potassium contents ranged from 1.31 to $2.59 \%$ with a mean of $1.85 \%$ (Table 3 ). This result showed that, about $50 \%$ of the coffee leaves were found to be low $(<2.1 \%)$ category as critical level suggested by [36] in leaf $\mathrm{K}$ concentration. The deficient in leaf $\mathrm{K}$ concentration was inconsistent with the soil exchangeable $\mathrm{K}$ test. The first reason low in leaf potassium contents could be due to the potassium is demanded and exported in large quantities by coffee, especially in years of high yield, since it has a direct relation with production or with fruit load [43]. This present study also similar to the findings of $[25,18,38]$ who reported the $\mathrm{K}$ concentration in plant leaves was inversed to exchangeable $\mathrm{K}$ in the soil test. In relation to this, Fanuel et al. [21] who concluded that $\mathrm{K}$ availability was not only considered from soil exchangeable $\mathrm{K}$ content. The reasons for the lack of leaf $\mathrm{K}$ is that, may be many control points and processes that allow plants to accumulate in their leaves from soil to leaf. Thus, the insufficient tissue $\mathrm{K}$ content may be related to nutritional imbalance resulting from cation competition, which may interfere with $\mathrm{K}$ availability. This result is also in agreement with [14], who reported the reduction in leaf $\mathrm{K}$ contents due to the increase in Mg quantity; hence result in decreased K uptake. Time of coffee leaf sampling also affects leaf $\mathrm{K}$ concentration. In research conducted by Dubberstein et al. [15] found that a reduction in leaf potassium concentration was to be observed from December to May and significantly affected by time. Apart from this, potassium concentration of Arabica coffee was relatively higher in fruits compared to leaves [15] thus this could be the reason for deficiency of tissue $\mathrm{K}$ content.

\subsubsection{Leaf Calcium Content}

Calcium contents in coffee leaves ranged from 0.75 to $1.50 \%$ with a mean of $1.02 \%$ in Table 3 . According to Reuter and Robinson [36], all of coffee leaves were categorized under optimum range. This result implies that calcium tissue analysis was consistent with exchangeable $\mathrm{Ca}^{2+}$ in soil test, which was contrary to TN and K. Besides this, calcium tissue was significant and positive interrelationship with its respective soil nutrient. In this study, it was found that the contents of calcium in coffee leaves were sufficient. This result is supported by [25, 18] who revealed that calcium contents in plant leaves found to be sufficient. In Arabica coffee, high contents of leaf calcium can be explained because of sufficient amount of exchangeable calcium in soils [40].

\subsubsection{Leaf Magnesium Content}

Magnesium contents ranged from 0.25 to $0.39 \%$ with a mean value of $0.31 \%$ in Table 3 . Magnesium content was found to be within the sufficiency range suggested by [36]. This result indicates leaf magnesium content followed the trend of tissue calcium concentrations. A possible reason for high contents of leaf magnesium of Arabica coffee could be due to the contributions of soil organic matter and content of exchangeable magnesium in soils. This study was supported by Sousa et al. [40] who reported that content of leaf $\mathrm{Mg}$ of coffee was significantly affected by soil exchangeable magnesium.

\subsection{Correlation Between Soil Macronutrients and Coffee Leaf Tissue}

Evaluation of soil test and tissue analysis results is decisive 
for sustainable soil fertility management. Thus, simple correlation analysis was conducted to determine the relationship between soil and coffee leaf in Table 4 . The result revealed that a positive correlation with their respective nutrients. However, TN did not show significant correlation with its respective soil nutrient concentration. Leaf $\mathrm{N}$ contents showed no direct relationship with SOM, because the mineralization and release rates of these nutrients to the soil solution can explained by the chemical composition of the residues and on the biotic and abiotic factors related with soils.

Table 4. Correlation between soil and plant tissue variables.

\begin{tabular}{llllll}
\hline \multirow{2}{*}{$\begin{array}{l}\text { Soil } \\
\text { parameters }\end{array}$} & $\mathbf{N}$ & $\mathbf{P}$ & $\mathbf{K}$ & $\mathbf{C a}$ & $\mathbf{M g}$ \\
\cline { 2 - 6 } $\mathrm{TN}$ & $0.47^{\mathrm{ns}}$ & $0.44^{\mathrm{ns}}$ & $0.27^{\text {ns }}$ & $0.38^{\text {ns }}$ & $0.23^{\text {ns }}$ \\
$\mathrm{Av} \mathrm{P}$ & $0.41^{\mathrm{ns}}$ & $0.87^{* *}$ & $0.63^{*}$ & $0.71^{*}$ & $0.52^{\text {ns }}$ \\
$\mathrm{K}$ & $0.67^{*}$ & $0.34^{\text {ns }}$ & $0.9^{* *}$ & $0.24^{\text {ns }}$ & $-0.19^{\text {ns }}$ \\
$\mathrm{Ca}$ & $0.19^{\text {ns }}$ & $0.39^{\text {ns }}$ & $0.41^{\text {ns }}$ & $0.77^{* *}$ & $0.05^{\text {ns }}$ \\
$\mathrm{Mg}$ & $0.39^{\text {ns }}$ & $0.7^{*}$ & $0.35^{\text {ns }}$ & $0.06^{\text {ns }}$ & $0.66^{*}$ \\
\hline
\end{tabular}

$* *=\mathrm{P} \leq 0.01 ; *=\mathrm{P} \leq 0.05 ; \mathrm{ns}=$ non-significant

Pearson correlation coefficient showed coffee leaf $\mathrm{P}$ content significantly positive correlated with soil $\mathrm{P}(\mathrm{r}=0.87)$, $\mathrm{Mg}(\mathrm{r}=0.7)$. This implies $\mathrm{K}$ plant tissue was significant and positive correlation with soil $\mathrm{P}(\mathrm{r}=63), \mathrm{K}(\mathrm{r}=0.9)$. This present result is agreement with results of [25, 18, 40]. Significant and positive correlation was found to be Ca leaf concentration with soil $\mathrm{P}(\mathrm{r}=0.71), \mathrm{Ca}(\mathrm{r}=0.77) . \mathrm{Mg}$ leaf content was significant and positive correlation with soil $\mathrm{Mg}$ $(\mathrm{r}=0.66)$. Similar result was observed by Sousa et al. [40] found that Calcium and $\mathrm{Mg}$ increased significantly in the diagnostic leaf along with increases in their exchangeable contents in the soil.

\section{Summary and Conclusion}

Result revealed soil $\mathrm{pH}$ ranged from strongly to moderately acidic. In soil test, result also revealed generally organic matter, $\mathrm{CEC}, \mathrm{TN}, \mathrm{Ca}, \mathrm{Mg}$ are within the accepted limits, whereas $\mathrm{K}$ is high category. However, available $\mathrm{P}$ was very low in all sampled soils. In plant tissue, result showed $\mathrm{N}, \mathrm{P}$ and $\mathrm{K}$ in deficient levels. However, $\mathrm{Ca}$ and $\mathrm{Mg}$ sufficient in plant tissue. The problems in the study sites might be related to low $\mathrm{pH}$, impact of continues cultivation without soil fertility intervention, nutrient mined due to harvested products, no application of mineral and organic fertilizer, coffee age, coffee cultivation practices and soil conservation measures.

This result concluded that soil test and tissue analysis were not completely dependable. Thus, two methods should be done at same period is required.

\section{Recommendations}

i. For sound conclusion, the following recommendations are suggested;

ii. soil survey should be taken from a number of coffee growing farms iii. Further studies based on soil test and crop response calibration should be conducted for fertilizer recommendation in the study area.

iv. Continuous monitoring of fertility status of the soil for quality evaluation should be carried out regularly

v. N, P, K and organic fertilizers should be added to coffee farms as well as lime should be applied in order to raise soil $\mathrm{pH}$ to a desired level.

\section{References}

[1] Abebe Nigussie, Gebremedihin Ambaw and Endalkachew Kissi. 2013. Fertility status of eutric nitisol and fertilizer recommendation using numass in the selected areas of Jimma zone, southwestern Ethiopia. Tropical and Subtropical Agroecosystems, 16: 48-495.

[2] Abiye Astatke, Tekalign Mamo, Peden, D. and Diedhiou, M., 2004. Participatory on-farm conservation tillage trial in the Ethiopian highland Vertisols: The impact of potassium application on crop yields. Experimental agriculture, 40 (3): 369-379.

[3] Abu Tafera. 2016. Ethiopia. Coffee Annual Report, Gain Report: ET615, USDA.

[4] Alemu Lelago, Tekalign Mamo, Wassie Haile and Hailu Shiferaw. 2016. Assessment and Mapping of Status and Spatial Distribution of Soil Macronutrients in Kambata Tembaro Zone, Southern Ethiopia. Advances in Plants and Agriculture Research, 4 (4): 144.

[5] Amare Haileslassie, Priess, J., Veldkamp, E., Teketay, D., Lesschen, J. P., 2005. Assessment of soil nutrient depletion and its spatial variability on smallholders' mixed farming systems in Ethiopia using partial versus full nutrient balances. Agriculture, Ecosystem and Environment, 108 (1): 1-16.

[6] Bohn, H. L., McNeal, B. L. and O’Connor, G. A., 2001. Soil Chemistry. 3rd Edition. John Wiley and Sons, Inc., USA.

[7] Bray R. H. and Kurtz, L. T., 1945. Determination of total, organic, and available forms of phosphorus in soils. Soil science, 59 (1): 39-46.

[8] Bremner, J. M. and Mulvaney, C. S., 1982. Nitrogen total. Methods of soil analysis. Part 2. Chemical and microbiological properties, (methods of soilan 2), pp. 595-624.

[9] Cannavo, W. J. O., Silva, C. A., Muniz, J. A., Savian, T. V., 2013. Mineralização de nitrogênio em Latossolos adubados com resíduos orgânicos. Rev Bras Cienc Solo, 37: 715-25.

[10] Chapman, H. D., 1965. Cation-exchange capacity 1. Methods of soil analysis. Part 2. Chemical and microbiological properties, (methods of soilanb), pp. 891-901.

[11] CSA (Central Statistical Agency), 2017. Agricultural Sample survey: report on area and production of major crops (private peasant holdings, Meher season). Statistical Bulletin, volume 1: Addis Ababa.

[12] Cyamweshi R. A., Nabahungu, N. L., Mukashema, A., Ruganzu V., Gatarayiha, M. C., Nduwumuremyi, A. and Mbonigaba, J. J., 2014. Enhancing nutrient availability and coffee yield on acid soils of the central plateau of southern Rwanda. Global Journal of Agricultural Research, 2 (2): 44-55. 
[13] De Mello Prado, R. and Caione, G., 2012. Plant Analysis. In Soil Fertility. InTech, 124p.

[14] Dias, K. G. D. L., Guimarães, P. T. G., Neto, A. E. F., Silveira, H. R. O. D. and Lacerda, J. J. D. J., 2017. Effect of Magnesium on Gas Exchange and Photosynthetic Efficiency of Coffee Plants Grown under Different Light Levels. Agriculture, 7 (10): 85

[15] Dubberstein, D., Partelli, F. L., Dias, J. R. M. and Espindola, M. C., 2016. Concentration and accumulation of macronutrients in leaf of coffee berries in the Amazon, Brazil. Australian Journal of Crop Science, 10 (5): 701.

[16] EthioSIS (Ethiopia Soil Information System). 2014. Soil fertility status and fertilizer recommendation atlas for Tigray regional state, Ethiopia. July 2014, Addis Ababa, Ethiopia.

[17] EthioSIS (Ethiopian Soil Information System). 2015. http://www.ata.gov.et/highlighted-deliverables/ethiopian-soilinformation-system-ethiosis/.

[18] Fanuel Laekemariam, Kibebew Kibret, Tekalign Mamo and Heluf Gebrekidan. 2016a. Soil-Plant Nutrient Status and their Relations in Maize-Growing Fields of Wolaita Zone, Southern Ethiopia. Communications in Soil Science and Plant Analysis, 47 (11): 1343-1356.

[19] Fanuel Laekemariam. 2016. Soil Nutrient Status of Smallholder Cassava Farms in Southern Ethiopia. Journal of Biology, Agriculture and Healthcare, 6 (19): 12-18.

[20] Fanuel Laekemariam, Kibebew Kibret, Tekalign Mamo, Erik Karltun and Heluf Gebrekidan. 2016b. Physiographic characteristics of agricultural lands and farmers' soil fertility management practices in Wolaita zone, Southern Ethiopia. Environmental Systems Research, 5 (1): 24.

[21] Fanuel Laekemariam, Kibebew Kibret and Hailu Shiferaw. 2018. Potassium (K)-to-magnesium $(\mathrm{Mg})$ ratio, its spatial variability and implications to potential $\mathrm{Mg}$-induced $\mathrm{K}$ deficiency in Nitisols of Southern Ethiopia. Agriculture and Food Security, 7 (1): 13

[22] Flores, R. A., Borges, B. M. M. N., Almeida, H. J. and De Mello Prado, R., 2016. Growth and nutritional disorders of coffee cultivated in nutrient solutions with suppressed macronutrients. Journal of Plant Nutrition, 39 (11): 15781588.

[23] Girma Nigussie. 2011. Marketing information operation in Ethiopia with special reference to the Ethiopia Commodity Exchange (ECX) Coffee Trading. MSc. Thesis. Swedish University of Agricultural sciences Uppsala, Sweden. Department of Urban and Rural development, XX, 75p.

[24] Hanisch, S., Dara, Z., Brinkmann, K. and Buerkert, A., 2011. Soil fertility and nutrient status of traditional Gayo coffee Agroforestry systems in the Takengon region, Aceh Province, Indonesia. Journal of Agriculture and Rural Development in the Tropics and Subtropics, 112 (2): 87-100.

[25] Hillette Hailu, Tekalign Mamo, Riikka Keskinen, Erik Karltun, Heluf Gebrekidan and Taye Bekele. 2015. Soil fertility status and wheat nutrient content in Vertisols cropping systems of central highlands of Ethiopia, Agriculture \& Food Security, 4 (1): 19.

[26] Horneck, D. A., Sullivan, D. M., Owen, J. S., Hart, J. M., 2011. Soil test interpretation guide. Oregon State University Extension Service, EC 1478, USA. 12p.
[27] International Food Policy Research Institute (IFPRI), 2010. Fertilizer and Soil Fertility Potential in Ethiopia. IFPRI, Washington DC, USA.

[28] IPMS, 2007. Improving productivity and marketing success of Ethiopian farmer project Gomma pilot learning woreda diagnosis and programdesign.www.ipmsethiopia.org/content/file/document/ PLS DPD/gomma.pdf.

[29] Kehali Jembere, Tekalign Mamo and Kibebew Kibret. 2017. Characteristics of agricultural landscape features and local soil fertility management practices in Northwestern Amhara, Ethiopia. Journal of Agronomy, 16 (4): 180-195.

[30] Landon, J. R., 1991. Booker Tropical Soil Manual: A Handbook for Soil Survey and Agricultural Land Evaluation in the Tropics and Sub Tropics. Longman Scientific and Technical, Essex, New York, USA, 474p.

[31] Loide, V., 2004. About the effect of the contents and ratios of soil's available calcium, potassium and magnesium in liming of acid soils. Agronomy research, 2 (1): 71-82.

[32] Nath, T. N., 2014. Status of macronutrients ( $\mathrm{n}, \mathrm{p}$ and $\mathrm{k}$ ) in some selected tea growing soils of sivasagar district of Assam, India. International Research Journal of Chemistry, 7.

[33] Núñez, P. A., Pimentel, A., Almonte, I., Sotomayor-Ramírez, D., Martínez, N., Pérez, A. and Céspedes, C. M., 2011. Soil fertility evaluation of coffee (coffea spp.) Production systems and management recommendations for the Barahona province, Dominican Republic. Journal of Soil Science Plant Nutrition, 11 (1): 127-140.

[34] Olorunfemi, I. E., Fasinmirina, J. T. and Akinola, F. F., 2018. Soil physico-chemical properties and fertility status of longterm land use and cover changes: A case study in Forest vegetative zone of Nigeria. Eurasian Journal Soil Science, 7 (2): 133-150.

[35] Price, K., Jackson, C. R., Parker, A. J., 2010. Variation of surficial soil hydraulic properties across land uses in the southern Blue Ridge Mountains, North Carolina, USA. Journal of Hydrology, 383 (3-4): 256-268.

[36] Reuter, D. J., Robinson, J. B., 1988. Plant Analysis: An Interpretation Manual. CSIRO, Melbourne, Australia.

[37] Rowell, D. L., 1994. Soil science: Methods and application. Addison Wesley Longman, Limited, England, UK 66, pp. 573-574.

[38] Shunfeng, G. E., Zhanling, Z. H. U., Ling, P. E. N. G., Qian, C. H. E. N. and JIANG, Y., 2018. Soil Nutrient Status and Leaf Nutrient Diagnosis in the Main Apple Producing Regions in China. Horticultural Plant Journal, 4 (3): 89-93.

[39] Smith, F. W., 1986. Interpretation of plant analysis: Concepts and principles. In: Reuter DJ, Robinson JB. (eds.), Plant analysis: An interpretation manual. Inkata, Melbourne, 19: 112.

[40] Sousa, J. S., Neves, J. C. L., Martinez, H. E. P. and Alvarez, V. H. V., 2018. Relationship between Coffee Leaf Analysis and Soil Chemical Analysis. Revista Brasileira de Ciência do Solo, 42.

[41] Taye Kufa. 2010. Environmental sustainability and coffee diversity in Africa. Paper presented in the ICO World Coffee Conference, 26-28 February 2010, Guatemala City. 
[42] Tegbaru Bellete. 2015. Soil Fertility Mapping and Fertilizer Recommendation in Ethiopia: Update of EthioSIS project and status of fertilizer blending plants. pp. 24-41. IPI-MoANRATA- Hawassa University Joint Symposium. The role of potassium in balanced fertilization. 24-26 November 2015, Hawassa University, Hawassa, Ethiopia.

[43] Valadares, S. V., Neves, J. C. L, Rosa, G. N. G. P., Martinez, H. E. P., Venegas, V. H. A. and Lima, P. C., 2013. Produtividadee bienalidade da produção de cafezais adensados sob diferentes doses de N e K. Pesq Agropec Bras, 48: 296303.

[44] Van Reeuwijk, L. P., 1993. Procedure for Soil Analysis. 4th Edition. International Soil Reference Center Wageningen. (ISRIC) Technical Paper no. 9. The Netherlands.

[45] Wakene Negassa and Heluf Gebrekidan. 2003. Forms of phosphorus and status of available micronutrients under different land-use systems of Alfisols in Bako area of Ethiopia. Ethiopian Journal of Natural Resources, 5: 17-37.

[46] Walkley, A. and Black, I. A., 1934. An examination of the Digestion method for determining soil organic matter and a proposed modification of the chromic acid titration method. Open Journal Soil Science, 37: 29-38.

[47] Wassie Haile and Shiferaw Boke. 2011. On-Farm Verification of Lime and NPK Fertilizers Effects on the Tuber Yield of Irish Potato (Solanum tuberosum) on Some Acidic Soils of Southern Ethiopia. Journal of the Drylands, 4 (1): 283-288.

[48] Maria, R. M. and Yost, R., 2006. A Survey of soil fertility status of four agro ecological zones of Mozambique. Soil Science, 171 (11): 902-914. 